\title{
A FANTASIA DO REAL NO CONTEXTO DA EDUCAÇÃO INFANTIL: DESCOBRINDO SENTIDOS E SIGNIFICADOS PARA UMA EDUCAÇÃO DIFERENCIADA
}

\author{
Denise Watanabe, Rosimeire Marques Gonçalves, Tony Aparecido Moreira, José Milton de Lima \\ Universidade Estadual Paulista - FCT/UNESP. Departamentos: Educação Física, Pedagogia e Educação, Campus \\ Presidente Prudente - SP. Email: de.wtnb@gmail.com. \\ Agência Financiadora: PIBIC/CNPq.
}

\section{RESUMO}

Este artigo expõe resultados de uma pesquisa de Iniciação Científica realizada em algumas salas de Educação Infantil de uma escola periférica de um município do interior paulista. Com o objetivo de estimular a imaginação infantil e ampliar o repertório lúdico das crianças e das professoras utilizou-se brincadeiras; histórias; personagens imaginários; fotos; observações; anotações no diário de campo; diálogos, questionários e entrevista com as crianças e as professoras. De natureza qualitativa e fundamentada na Sociologia da Infância, adotou-se a metodologia da pesquisa-intervenção, com vista a levantar reflexões teóricas e práticas que colaborassem com transformações na realidade. Como resultados destacam-se uma efetiva participação das crianças nas brincadeiras e atividades; avanços nas relações com a pesquisadora e com os pares infantis; a maior valorização do espaço educativo e das culturas infantis pelos envolvidos na pesquisa e a solicitação de crianças e de adultos para que a pesquisa se ampliasse a outras seriações.

Palavras-chave: Sociologia da Infância, Imaginação, Ludicidade, Infância, cultura de pares.

\section{THE REAL FANTASY IN THE CONTEXT OF EARLY CHILDHOOD EDUCATION: DISCOVERING SENSES AND MEANINGS FOR A DIFFERENTIATED EDUCATION.}

\begin{abstract}
This article presents results of a survey of scientific research carried out in some early childhood classrooms of a school municipality of peripheral state of São Paulo. In order to stimulate children's imagination and broaden the Repertoire of the teachers and children's playful used jokes; stories; imaginary characters; pictures; observations; Notes on field journal; dialogues, questionnaires and interviews with the children and the teachers. Qualitative in nature and based on the Sociology of childhood, adopted the methodology of intervention research, with a view to raising the theoretical and practical reflections that collaborate with changes in reality. As results are an effective participation of children in games and activities; advances in relations with the researcher and with infant pairs; the greater appreciation of space education and child cultures by those involved in the research and the request of children and adults for the survey if widen other rankings.
\end{abstract}

Keywords: Sociology of childhood, Imagination, Playfulness, Childhood, culture-pairs. 


\section{INTRODUÇÃO}

Este artigo expõe resultados de uma pesquisa de Iniciação Científica intitulada "No mundo da criança: resgatando a fantasia do real no contexto da Educação Infantil", financiada pelo CNPq e realizada em algumas salas de Educação Infantil - I e II de uma escola periférica de um município do interior paulista. Surgiu em 2011, ao constatar - por meio de intervenções e observações - que algumas salas daquele contexto apresentavam algumas dificuldades e entraves para incentivar e ampliar a imaginação infantil, assim como uma carência - por parte dos alunos - em expressá-la nas brincadeiras e nas atividades propostas.

Durante um momento de brincadeiras, um aluno expressou de forma imaginativa que era um "super-herói". No entanto, obteve como resposta de sua professora: "- se você é um super-herói então eu sou a Hebe". Após perceber o recuo da criança - o bolsista inicial aproximou-se com uma capa improvisada e iniciou um diálogo amigável: - Eu sou um super-herói! Ao perceber que lhe davam voz e oportunidade para se expressar, o aluno novamente deu "asas à imaginação": - Você é um superherói? Eu também!

Ambos se aventuravam pela escola, felizes. O aluno - por ter o seu direito de fala reconhecido e por ter a oportunidade de expressar sua imaginação e seus sentimentos durante as atividades - e o pesquisador - por ser e/ou fazer a diferença naquele momento e pensar em uma pesquisa que pudesse transformar aquela realidade/contexto.

Entretanto, em momento algum, se pretendeu culpar ou mesmo julgar essas professoras ou quaisquer pessoas envolvidas com a pesquisa pelos problemas e desafios encontrados no contexto, já que os problemas relacionados à educação brasileira são complexos e requerem estudos mais amplos.

$\mathrm{O}$ intuito era incentivar e ampliar a imaginação, além de enfatizar a sua importância, já que, por meio da imaginação - possibilitada pelas experiências e vivências reais - as crianças podem compreender situações; superar medos; ajustar experiências, sentimentos e emoções; aprender sobre si e sobre o outro, entre outros.

Para Ferreira (2008, p. 18):

[...] a fantasia do real, longe de ser um "erro de adaptação", permite à criança compreender, interpretar e agir no meio social, sendo um recurso que permite experimentar $\mathrm{e}$ ajustar experiências e emoções através da mutação/confronto do/com o real; um recurso no caminho da criança como 
"actor e construtor social de si própria" (SARMENTO, 2001: 9), com o pleno uso de capacidades de transfigurar a linearidade do espaço do tempo e de "si".

A imaginação está relacionada com a linguagem simbólica, com símbolos captados do mundo real através das experiências vividas - transpostas do real para o imaginário - por meio da escuta ou observação de cenas, de sons, de imagens, de objetos. Esse fato demonstra que a imaginação não acontece de forma natural ou no vazio social, mas tem relação com as vivências e experiências, com as mediações e contextos ao qual a criança está inserida. Ela é inerente à "[...] formação e desenvolvimento da personalidade e racionalidade de cada criança concreta" o que "[...] acontece no contexto social e cultural que fornece condições e as possibilidades desse processo" (SARMENTO 2002, p. 3).

Segundo as ideias de Held e interpretadas por Stort (1989, p. 50) “[...] o real vem em primeiro lugar e o imaginário, em segundo", ou seja, são das experiências (diversificadas, ricas e significativas) do mundo real que se torna possível expandir a imaginação. Ferreira, fundamentado em Harris (1996, 2002 apud FERREIRA, 2008, p. 18) enfatiza que a imaginação:
[...] contribui para a emergência da objectividade nas crianças, uma vez que permite colocar lado a lado realidades possíveis, elaborar julgamentos morais e aprender com a experiência "de um outro", ainda que imaginário, conseguindo a criança distinguir claramente $o$ mundo real e o mundo da imaginação.

Além de estudos sobre o imaginário, a Sociologia da Infância representa uma área que enfatiza a necessidade de valorizar a criança e a infância. Nela, encontramos os quatro eixos estruturadores das culturas infantis idealizados por Sarmento (2002), os quais organizam "[...] formas específicas de inteligibilidade, de representação e de simbolização do mundo" (DELGADO apud REVISTA EDUCAÇÃO, 2013, p. 23). Elementos das "culturas da infância" (ou culturas infantis) que se constituem "[...] capacidade das crianças em construírem de forma sistematizada modos de significação do mundo e de acção intencional, que são distintos dos modos adultos de significação e aç̧ão" (SARMENTO, 2002, p. 4).

As culturas da infância marcam e expressam, mesmo que de formas divergentes, algumas características presentes no cotidiano infantil, representados pelos quatro eixos estruturadores das culturas infantis: a 
ludicidade (brincar), a fantasia do real (imaginação), a interactividade (interação com os pares ou com o adulto) e a reiteração (um tempo que pode ser contabilizado de forma recursiva, sem prejuízos à brincadeira). Cada eixo estruturador possui características singulares, mas também podem se interrelacionar.

O desafio do pesquisador significa captar e perceber as expressões e produções culturais infantis, ou seja, aguçar o ouvido e o olhar para cada criança, compreendendo suas linguagens e a autenticidade de cada uma delas.

Para Monteiro e Carvalho (2011, p. 638):

[...] o desafio do pesquisador está em aguçar o olhar e ouvir atentamente as crianças e construir ferramentas que captem suas expressões e que possibilitem a percepção do que têm em comum, suas produções culturais. As crianças significam o mundo por meio das linguagens: falar, brincar, desenhar, imaginar, experimentar o corpo, são expressões e modos de apreensão simbólica do mundo. E elas o fazem na interação com outras crianças e com os adultos. Nessa interação a criança compreende o mundo e experimenta múltiplas emoções e afetos. $\mathrm{Na}$ medida em que tomamos suas produções simbólicas como legítimas, essas produções podem ser analisadas como expressões de uma cultura geracional construída no interior de e no diálogo com a cultura mais ampla.

O primeiro eixo estruturador a ser destacado é a ludicidade. Comum a todos os seres humanos, ocupa grande parte do tempo e do cotidiano infantil (embora os adultos também brinquem). A diferença é que, pelo fato de os adultos trabalharem e/ou assumirem outras responsabilidades brincar, muitas vezes, assume um papel secundário, restrito a momentos livres ou de lazer.

Para Sarmento (2004, p. 15):

A ludicidade constitui um
traço fundamental das
culturas infantis. Brincar
não é exclusivo das
crianças, é próprio do
homem e uma das suas
atividades sociais mais
significativas. Porém, as
crianças brincam, continua
e abnegadamente.
Contrariamente aos
adultos, entre brincar e
fazer coisas sérias não há
distinção, sendo o brincar
muito do que as crianças
trazem de mais sério.

Brincar permite o amplo desenvolvimento social, motriz, cognitivo, cultural; estimula a atenção, a linguagem; trabalha a socialização com os pares e com os adultos, entre outros. 
Como afirma Bochorny (2012, p. 82):

As brincadeiras têm influência constante no desenvolvimento das diversas faculdades humanas da criança, como - pensamento, a imaginação, a atenção, a concentração, a memória, a socialização, a linguagem, a personalidade, o domínio da vontade, a motricidade; elas "preparam" a criança para lidar com obrigações sociais (MUKHINA, 1995).

O segundo eixo estruturador é a fantasia do real, que possui estreita relação com a ludicidade. A imaginação, segundo Sarmento $(2003$, p. 3) é "[...] inerente ao processo de formação e desenvolvimento da personalidade e racionalidade de cada criança concreta" e [...] que acontece "no contexto social e cultural que fornece as condições e possibilidades desse processo", ou seja, ela não ocorre no "vazio social", mas, através das relações da criança com os pares infantis, com outros mais experientes do que ela ou com os adultos.

Rodari (1982) considera a participação adulta na brincadeira de suma importância, já que, pelo fato dele ser mais experiente, contribuiria para potencializar a capacidade imaginativa das crianças. $\mathrm{Na}$ brincadeira, $\mathrm{O}$ adulto ensina a criança a brincar, colocandose ao seu serviço. Ele proporciona uma forma de incentivá-la.

Conforme Rodari (1982, p. 105-106):
Não se trata, é claro, de brincar "no lugar da criança" relegando-a ao humilhante papel de espectadora. Trata-se de se colocar a seu serviço. É ela quem comanda. Brinca-se "com ela", "para ela", para estimular sua capacidade inventiva, para dar-lhe novos instrumentos que serão usados quando brincar sozinha, para ensiná-la a brincar. Enquanto se brinca, se fala. Aprende-se com a criança a falar com as peças do jogo, a compreender seus nomes e papéis, a transformar um erro em uma invenção, um gesto em uma história [...].

Assim como a ludicidade, a imaginação não é restrita apenas às crianças, mas comum a todos os seres humanos. Sarmento (2003), referenciando Harris (2002), afirma que existe uma transposição imaginária do real comum a todos, adultos e crianças. E, embora a imaginação seja maior nos adultos (devido as suas experiências serem maiores), isso não significa que ela seja inferior nas crianças.

Para Paula (2008, p. 139):

Perceber a atuação das crianças nas relações sociais e no interior dos espaços em que circulam diariamente é compreender que elas produzem sentidos para as experiências que vivenciam, tomando como referência o sistema simbólico que as envolve. 
Também partilham significados que, embora diferentes dos adultos, não significa que sejam inferiores.

Para Lima e Lima (2013, p. 212), a presença da imaginação nas brincadeiras e “[...] nos jogos de imaginação ou de papéis é, sem dúvida, uma maneira privilegiada de contato com o outro, o mundo e a cultura. Brincando, as crianças se apoderam criativamente de formas e práticas sociais, aprendendo sobre si mesmas e sobre o mundo em que vivem".

Além das brincadeiras, histórias e atividades para estimular a fantasia do real, contamos com o respaldo de dois amigos imaginários - o Lipe e a Luci - personagens situados nos enredos das culturas infantis aos quais nunca foram citadas características físicas.

Ferreira (2008, p. 14) enfatiza que,

É nos meandros das culturas da infância que situamos os Amigos Imaginários, as "criações invisíveis", ou objectos personificados, a "quem" as crianças dotam de vida e com os quais interagem; e cuja fundamentação da sua gênese necessitou de um cruzamento

multidisciplinar, com a Psicologia, Medicina e Neurobiologia. "Criações invisíveis" que, assumindo o papel de amigos ou irmãos das crianças, se tormam seus companheiros nas aventuras quotidianas... os seus aliados nos momentos "difíceis"... a expressão (e o alcance) da vontade e do desejo... a possibilidade de eliminar os constrangimentos que a realidade apresenta e de viver as oportunidades da fantasia... explorando (e aprendendo com) todas as (suas) contradições e possibilidades... (re) construindo e (re) construindo-se...

O terceiro eixo estruturador das culturas infantis a ser destacado é a interactvidade, ou seja, a relação das crianças com os "pares" ou com os adultos. O conceito de pares refere-se "[...] a coorte ou - grupo de crianças que passa seu tempo junto quase todos os dias" (CORSARO, 2011 p. 127). As crianças "[...] criam e participam de suas próprias e exclusivas culturas de pares quando selecionam ou se apropriam criativamente de informações do mundo adulto para lidar com suas próprias e exclusivas preocupações" (p. 31). O autor define cultura de pares como "[...] um conjunto estável de atividades ou rotinas, artefatos, valores e preocupações que as crianças produzem e compartilham em interação com as demais (CORSARO, 2003; CORSARO; EDER, 1990 apud CORSARO 2011, p. 128)". 
Para Sarmento (2004 p. 14), a cultura de pares:

[...] permite às crianças apropriar, reinventar e reproduzir o mundo que as rodeia. A convivência com os seus pares, através da realização de actividades e rotinas, permite-lhes exorcizar medos, representar fantasias e cenas do quotidiano, que assim funcionam como terapias para lidar com experiências negativas. Essa partilha de tempo, acções, representações e emoções é necessária para um mais perfeito entendimento do mundo e faz parte do crescimento.

O quarto e último - mas não menos importante eixo estruturador - é a reiteração. Um tempo destinado ao brincar que, quando prazeroso, parece contabilizado de forma diferente dos padrões cronológicos do ponteiro do relógio: duas horas "parecem" apenas cinco minutos. É um tempo recursivo que possibilita recomeçar sem prejuízos a brincadeira sem perder sua graça e significado, permitindo recomeçar "várias e várias vezes", "mais uma vez" ou ainda "de novo".

As culturas infantis funcionam como a prova da alteridade da infância. Elas demonstram que as crianças não são passivas ou apenas absorvem e/ou reproduzem a cultura adulta, mas que participam ativamente delas, como atores sociais, como construtoras do processo de socialização junto com os adultos.

Ferreira, ao referenciar Sarmento, enfatiza que a criança significa:

[...] um actor social da sua própria socialização. Uma socialização que se funda na sua interacção com o meio e com os outros, crianças e adultos, em contextos sociais com características específicas, num processo através do qual as crianças aprendem, elaboram e assumem normas e valores da sociedade em que vivem (cf. Sarmento 2000b e 2003b); um processo realizado por um sujeito concreto e singular, com vontades, saberes, capacidades, emoções, desejos e afectos que o identificam como um "produtor cultural único" [...] (SARMENTO, 2007, p. 2 apud FERREIRA 2008, p. 16).

Apesar das culturas infantis ressaltem as diferentes e ativas formas de participação infantil no mundo ainda é possível encontrar principalmente nos espaços institucionalizados criados por adultos para as crianças - práticas verticais que valorizam somente o conhecimento dos professores e o ensino dos saberes, tidos como prioritários, como os linguísticos. Em decorrência, acabam por desconsiderar as outras linguagens, como a imaginação e a 
ludicidade, imprescindíveis para as crianças.

Falta, portanto, compreender importância de cada componente, dimensionar seu valor e incentivá-los.

Para Honorato:

Os diversos aspectos sobre a criança que aparecem nas diferentes produções artísticas mostram que a imaginação é um lugar de memória. É um lugar de ação. Será que este lugar está sendo considerado na sociedade, na escola, na família, como significativo para o desenvolvimento infantil?

Os espaços institucionalizados abrigam grande número e concentração de crianças, o que contribui para que, muitas vezes, as falas e a participação infantis sejam olvidadas. Apesar de as crianças passarem grande parte de sua infância nesses espaços que na contemporaneidade tem sofrido transformações - ainda é possível perceber uma negatividade da criança.

Para Sarmento (2003, p. 2-3), essa negatividade está relacionada com a construção social da infância pela modernidade: "criança é o que não fala (infans), o que não tem luz (a-luno), o que não trabalha, o que não tem direitos políticos, o que não é imputável, o que não tem responsabilidade parental ou judicial, o que carece de razão, etc." Tais entendimentos representam uma série de conceitos de criança e de infância que surgiram e evoluíram conforme determinadas sociedades, épocas, processos históricos e sociais, visões adultas, os quais precisam ser superados.

Entretanto, em momento algum desconsideramos o papel da Educação Infantil na vida das crianças. Antes, ressaltamos e reconhecemos a importância desses locais para propiciar, trocar e fomentar experiências e aprendizagens. Sarmento afirma a importância das instituições educacionais e dos espaços domésticos para as aprendizagens de códigos utilizados criativamente e que se constituem base das culturas infantis:

A relação particular que as crianças estabelecem com a linguagem, através da aquisição e aprendizagem dos códigos que plasmam e configuram o real, e da sua utilização criativa, constitui a base da especificidade das culturas infantis. Ora, esta aquisição e aprendizagem é desenvolvida predominantemente nas instituições educacionais (jardins de infância e escolas), tanto quanto nas interações realizadas no espaço doméstico, através da educação familiar. (SARMENTO, 2002).

Como afirma Bochorny (2012, p. 7374) "compreender o status da infância nas agências socializadoras é relevante, uma vez que são as agências que podem propiciar 
mediações salutares ao desenvolvimento integral dos sujeitos [...]". É preciso, portanto, compreender o espaço da Educação Infantil, as crianças e as suas infâncias.

\section{OBJETIVO}

Os objetivos da pesquisa visavam a estimular a imaginação infantil - por vezes latente - e ampliar o repertório lúdico e imaginativo das crianças e das educadoras, além da tentativa em superar - por meio do respaldo teórico da Sociologia da Infância - as práticas que não favoreciam ou que não incentivavam a fantasia do real e a ludicidade como linguagens imprescindíveis para as crianças do contexto escolar.

\footnotetext{
Objetivos que exigem aprofundamento teórico e práticas educativas com "intencionalidade", que valorizem, compreendam e incentivem a imaginação (e a ludicidade). Como afirma Bochorny (2012), é necessário mediar o processo e perceber os benefícios das ações educativas, ou seja:
}

[...] perceber em que essa ação pode beneficiar a criança e mediar o processo, tanto quanto for necessário; vivenciá-la com as crianças, para poder entender como essa atividade pode propiciar formas de atuar menos invasivas e mais assertivas; oportunizar espaços, tempo e materiais que contribuam para melhoria da qualidade do brincar. (2012, p. 82)

Representa, portanto, um grande desafio para as escolas do século XXI e seus professores superar as práticas e os conceitos antigos e verticalizados sobre criança e infância.

Para Lima e Lima (2003, p. 209):

As escolas de Educação Infantil estão sendo desafiadas, frente à infância do século XXI, a atuarem de maneira distinta da que se constata no contexto histórico atual. Para tanto, precisam buscar respaldo em concepções que reconheçam a criança como ator social, superando a compreensão veiculada por séculos, que a concebia como simples receptora da cultura ou como agente a ser incorporada nos contextos sociais por intermédio de processos de socialização conduzidos pelos adultos, sem considerar as especificidades, as opiniões e os significados por ela atribuídos para o que the era proposto.

Os objetivos propostos visavam valorizar, incentivar e/ou ampliar a imaginação e a ludicidade como imprescindíveis para o amplo desenvolvimento infantil - nos aspectos sociais, culturais, históricos, motores, cognitivos, afetivos, entre outros - 
principalmente no contexto da Educação Infantil.

\section{METODOLOGIA}

A presente pesquisa está amparada no Protocolo do Comitê de Ética em Pesquisa (CEP): Processo no 71/2009, da FCT/UNESP de Presidente Prudente.

Durante todo o percurso da pesquisa - suscitamos levantar reflexões sobre os desafios encontrados pela fantasia do real no contexto analisado com vista a contribuir para ampliá-la e estimulá-la nas crianças. Para tanto, utilizamos vários recursos, como:

- Histórias; brincadeiras; atividades lúdicas; brinquedos; desenho; fotos; música; teatro; objetos; amigos imaginários - Lipe e Luci - aos quais nunca foram descritas características físicas;

- Observações e anotações no Diário de Campo; gravações; fotos (tiradas por nós e pelas crianças). Os dados coletados foram sistematizados para melhor compreensão dos resultados.

- Questionário (realizado em novembro de 2013) e entrevistas (efetivadas em junho de 2014) com vistas a obter um "feedback" das professoras e das crianças sobre a pesquisa.

De natureza qualitativa e fundamentada na Sociologia da Infância, a pesquisa adotou a metodologia da Pesquisa-
Intervenção, já que os resultados e avanços que contavam eram aqueles com vista a transformar gradativamente a realidade.

Por qualitativo, Silva (2005, p. 20) considera:

[...] que há uma relação dinâmica entre $o$ mundo real e o sujeito, isto é, um vínculo indissociável entre o mundo objetivo e a subjetividade do sujeito que não pode ser traduzido em números. A interpretação dos fenômenos e a atribuição de significados são básicas no processo de pesquisa qualitativa. Não requer o uso de métodos e técnicas estatísticas. 0 ambiente natural é a fonte direta para coleta de dados e o pesquisador é o instrumento-chave. É descritiva. Os pesquisadores tendem a analisar seus dados indutivamente. $\mathrm{O}$ processo e seu significado são os focos principais de abordagem.

O uso de recursos metodológicos diversificados e significativos se justifica pelo fato de a fantasia do real não ocorrer no vazio social, mas conforme as vivências e experiências proporcionadas às crianças.

\section{RESULTADOS}

A participação das crianças e a escuta atenta de suas falas foi fundamental para a pesquisa. Além delas, ouvimos e dialogamos com as professoras participantes na 
pesquisa. $\mathrm{O}$ respeito, a seriedade e a proximidade com os sujeitos envolvidos permitiu observar, recolher e sistematizar muitos dados e resultados - destaque para aqueles em que houve maior expressividade lúdica e, principalmente, imaginativa.

Certo dia, uma das crianças trouxe para a escola uma geleia que parecia uma "meleca". As outras crianças pediram para pegá-la um pouco. Uma delas passou no dedo e disse que iria esfregá-la na "cara". Essa mesma criança queria esfregá-la em meu rosto: - Ô Denise, eu to cheia de geleia.

A cena despertou o interesse de outras crianças, que também vieram com suas mãos sujas, tentando esfregá-las em mim. Elas corriam e gritavam alvoroçadamente: - Eca! Eca!

Elas tentavam partilhar esse artefato, já que não era comum ver brinquedos na escola. Portá-lo, além de causar um "status" ao dono, ultrapassava as demarcações imaginárias da "tênue linha" entre o "escondido" (trazer o brinquedo na escola e mostrar às outras crianças que não o portavam) e o "divertido" (o alvoroço e a situação causados por esfregá-lo no rosto e nos dedos), além de contribuir para fomentar as relações com os pares, que, de fato, se divertiam não somente com o brinquedo, mas com o fato de a pesquisadora também fazer parte da brincadeira.
Outro resultado interessante ocorreu quando uma criança pediu para contar uma "história". Nela foi possível observar elementos que conciliavam o real e o imaginário. A criança inseriu os amigos da escola, mesclou situações e experiências reais (vividas por ela) com histórias de faz de conta:

- Era uma vez, Ana Luíza. Ela morava num castelo com um príncipe que chamava Kauã (tia, não anota Kauã que ele briga). O príncipe dela foi comprar comida para os filhos dela e ela ficou sozinha. Aí aconteceu um temporal e o castelo dela quase desmontou e o namorado dela não tava lá. Socorro! Socorro! o meu castelo tá desmoronando. A princesa procurou o príncipe e não achava, aí quando ela chegou na casa dela, o castelo tava todo molhado pelo temporal e os passarinhos cantando. Os filhinhos acordaram com fome e ela deu um banho no nenê. Ensaboou aí a mamãe deixou eles dormindo, etc... (DIÁRIO DE CAMPO 2013).

A história mesclava vivências reais (re) significadas pela imaginação infantil.

Para Honorato:

O impulso criador do cérebro humano não se limita a reproduzir: ele combina, reelabora, cria com elementos de experiências passadas novas formas e traçados. Esta atividade criadora é alicerçada, sobretudo, 
naquilo que a psicologia chama imaginação ou fantasia. A imaginação se manifesta por igual em todos os aspectos da vida cultural, possibilitando a criação artística, científica e técnica.

Outro resultado que merece destaque ocorreu ao levarmos uma brincadeira que nomeamos de "bicho que pega". Era um pedaço de cartolina recortado em forma de círculo e com canudo de jornal que servia de corpo. As crianças deveriam desenhar (conforme a imaginação) como achavam que era esse "bicho que pega". Muitas crianças associaram-no com "vampiros", expressando e (re) interpretando imaginativamente fatos, situações, formas de agir e pensar conforme as experiências reais que tiveram ao brincar, assistir TV, ler livros, ouvir histórias, etc. Elas corriam uma atrás das outras como vampiros e falavam: - Vou comer!

Com tantos vampiros, resolvemos perguntar às crianças de onde havia surgido aquela "ideia".

Pesquisadora: - Onde você viu vampiro?

\section{Criança: - No meu sonho!}

Outra criança encosta o seu vampiro no meu pescoço, expressando: - "Delicius". A mesma criança apontou o seu "vampiro" para a professora e avisou: - "Tô" de olho em você (DIÁRIO DE CAMPO 2013).
As crianças - ao perceberem que eram ouvidas - passaram a se aproximar e a dialogar conosco, o que permitiu recolher muitos dados e resultados. Elas partilhavam experiências; expressavam desejos, curiosidades, contentamentos: - Você senta na nossa mesa? - Eu vou sentar lá na frente!; - Senta com "nóis" (DIÁRIO DE CAMPO 2013).

Outro fato interessante ocorreu quando indagamos às crianças o que elas pensavam sobre a temática da pesquisa, ou seja, sobre a imaginação.

Elas responderam: - Imaginação é uma coisa que inventa alguma coisa e aí faz o que você pensou. Inventa o que pensou; - Eu assisto um desenho da imaginação que ele faz um monte de coisa; - Imaginação é pensar alguma coisa para brincar, mas quando acordar, brincar; dormir quietinho.

Pesquisadora: - Mas será que só crianças imaginam?

Criança: - Não! Adulto também imagina (DIÁRIO DE CAMPO, 2013).

Mais um resultado a ser destacado relaciona-se com a forma de a criança utilizar a imaginação para lidar ou superar medos. Muitos deles são expressos de forma imaginária: - O pai de uma criança já matou um monte de cobra; - Tenho medo de dragão de duas cabeças; - Meu pai e meu irmão tem medo de tudo; - Minha mãe tem medo de mula sem cabeça; - Eu tenho medo de 
cachorro de quatro patas e cinco cabeças; Bicho papão tem amigo?

Pesquisadora: - Eu acho que o bicho papão está na escola!

Criança: - A gente vai morrer!

Pelo fato do bicho papão ter sido citado pelas crianças e ele constituir-se um personagem conhecido por cativar os medos infantis, resolvemos perguntar como ele era.

As crianças responderam: - Bicho papão é grande; com asas; garras e pega a gente; debaixo da cama; vive na mata; mata; come; não tem asas; três pés e três cabeças; 40 olhos, metade zumbi; bicho papão é caramujo; medo de lobo (DIÁRIO DE CAMPO 2014).

As crianças expressaram a imaginação em diversos momentos, nas brincadeiras, durante o recreio. Fizemos um "bilboquê" com copo descartável e decorado com um tubarão de EVA. Na extremidade colamos um peixe, na qual, as crianças deveriam acertá-lo dentro do copinho. Durante a brincadeira, algumas crianças cataram seu bilboquê e levaram até um formigueiro. Utilizando o copinho-tubarão, elas começaram a colocar terra e formiga dentro dele e a se alvoroçarem, chamando a atenção de outras crianças que correram para observar o que estava acontecendo: - O tubarão tá comendo terra. Pesquisadora: - Mas e se ele ficar doente? Criança: - Aí a gente interna ele. Pesquisadora: - Mas tubarão come formiga?
Crianças: - Come e morre; - Morreu! Pesquisadora: - Do que? Crianças: - De tanto comer areia; - Argh! Que nojo! Outras crianças, após assistirem as cenas, passaram a repeti-las: - O meu morreu; - Tá saindo sangue, todo mundo pra trás! Pesquisadora: Por quê? Crianças: - Porque ele comeu muita terra e formiga; - Tá cheio de sangue, credo; O meu tubarão não morreu; - Prô (referindose à pesquisadora) não morreu? Tá tudo bem com ele depois de tanta terra que ele comeu?; - Tá. Outra criança apontou, olhou para o sangue imaginário e disse: - O tubarão tá bravo com os dois. Pesquisadora: - Por quê? Criança: - Porque sim. Porque ele quer lutar. Pesquisadora: - O tubarão gosta mais de formiga ou de peixe? Crianças: - Formiga; O tubarão vem vindo!; - Tô me divertindo! Algumas crianças saíram do formigueiro e dirigiram-se para uma área com grama. Pesquisadora: - O que o tubarão está fazendo? Criança: - Comendo grama. Uma das crianças escorregou e, em seguida com um sorriso disse: - Comeu e caiu.

As outras crianças também começaram a descer na grama e escorregar. Umas fizeram um barulho, que parecia um rugido de urso:- Grauuu; - O meu quer comer o bicho prô.

Outro grupo de crianças - que também havia assistido as cenas da formiga se dirigiram à área com grama. Então, começaram a imitar e também a (re) 
significar o que viram, criando novas formas de brincar, cheias de significado. A partir do que viram (real), passaram a (re) expressar outras formas por meio da imaginação: - $O$ meu morreu!

Pesquisadora: - Morreu? Por quê?

Crianças: - Porque comeu um monte de grama; - Prô (referindo-se à pesquisadora), o meu tem umas garras, agora ele tá forte!

Outra criança colocou o copinho na boca e fez de "telefone". Depois, colocou-o na orelha e falou: - Alô? Alô?! (DIÁRIO DE CAMPO, 2014).

Outra brincadeira que contribuiu para estimular e compreender sobre a imaginação infantil foi quando levamos um cartaz cujo personagem principal era um jacaré. Nas extremidades do cartaz havia desenhos que deveriam ser escolhidos pelas crianças para realizar as atividades: dança e música do jacaré, brincadeira do vivo ou morto jacaré, etc. Antes de começar a brincadeira comentamos que na escola havia um jacaré.

As crianças, eufóricas falavam: - Eu tenho medo!

Juntas, elas passaram a expressar uma sequência de ideias imaginativas sobre o jacaré e o medo dele: - $E$ se eles comem a nossa barriga e cortam a nossa cabeça; - E arrancam a cabeça e cozinham a gente; - E tiram nosso dente; - Nosso nariz; - E tira a nossa boca; - Nosso cabelo; - Tiram a orelha;
- Tiram a boca; - A carne; - A perna; - Eu vou cortar esse jacaré; - Ele vai cortar a gente no meio; - Vou cortar o jacaré - Cortar ele no meio; - Prô (referindo-se à pesquisadora) ele vai tirar a unha da gente; - O jacaré do mau; Deixa ele morder; - Vai comer a sua cabeça (DIÁRIO DE CAMPO, 2014).

Ao expressarem o medo do jacaré, as crianças demonstraram o que fariam com ele ou o que ele poderia fazer com elas. No entanto, elas sabiam que era uma brincadeira, ou seja, algo da "imaginação".

$\mathrm{Na}$ outra sala - antes de começar a mesma atividade - brincamos que seriam elas a contar a história do jacaré. As crianças começaram a "encenar um choro". Ao perguntamos o motivo elas responderam que "tinham medo de jacaré" e "que não sabiam contar história".

Outras professoras que não participavam da pesquisa passaram a solicitar que ela se estendesse às outras seriações, como o Ensino Fundamental Ciclo I: - Vocês têm que dar aula para as outras salas também.

Além das professoras, as crianças argumentavam - ao saberem que a pesquisa seria efetuada somente o infantil: - Ah, mas podia ter aula pra gente; - Por isso que é difícil a gente ser as mais velhas. A gente não brinca de nada!

Diante dessas afirmativas, revolvemos questionar e ouvir os motivos pelos quais as 
crianças solicitavam a pesquisa: - Ah... pra

gente brincar, pra gente se divertir.

Pesquisadora: - Vocês brincam em casa?

Criança: - Não dá!

Pesquisadora: - Por quê?

Criança: - Porque só tem eu e a minha irmã, aí não dá para brincar! (DIÁRIO DE CAMPO 2013)

Outras crianças mais velhas também requisitavam as brincadeiras: - Prô, porque você não dá aula pra gente?; - Porque na verdade quando a gente entrou aqui não tinha nada disso (se referindo à pesquisa), nada, nada. A gente só ficava estudando.

Pesquisadora: - Mas vocês acham que agora que tem brincadeira na escola ficou mais legal?

Criança: - Mas a gente não brinca de nada! Só na Educação Física.

A brincadeira possui estreita relação com a imaginação. Brincando, a criança aprende a controlar as emoções, os medos, os sentimentos e anseios, aprende a compartilhar, a imitar a (re) criar, a eliminar os constrangimentos reais através da fantasia. Para isso, é necessário:

[...] repensar os tempos de brincar, e aceitar que as crianças são activas nas suas aprendizagens e nas aprendizagens dos seus pares; que são criativas e capazes de arranjar estratégias para superar as barreiras e resolver problemas que o dia a dia Ihes apresenta, para resistir aos constrangimentos dos seus mundos sociais; que expressam os seus desejos, medos, angústias e desejos e que, durante o brincar, projectam as suas necessidades e aprendem a moderar as suas emoções. Que as crianças são capazes de se (re) construir e (re) inventar a realidade, de acordo com as suas vontades e necessidades... eliminando os constrangimentos reais com as possibilidades que a fantasia lhes apresenta. (FERREIRA, 2008, p. 34)

\section{O recreio escolar proporcionou} momentos valiosos, possíveis por meio da escuta atenta das falas infantis, que expressavam assuntos variados, como dizer que estavam "gordas"; perguntar se "brincaríamos com elas (outras seriações)"; comentar sobre a cultura produzida e (re) significada por outras crianças.

Duas meninas de braços dados durante o recreio. Uma delas segurava um buquê de flores nas mãos e, ambas saíam andando de um lado para o outro. Perguntamos o que faziam e uma das crianças respondeu que as crianças estavam "brincando de casamento".

Intrigada para saber onde elas conseguiram aquele ramalhete de flores, continuei: - Onde elas pegaram flores? 
Rindo, as crianças responderam: - No lixo!

O sinal para retornarem para a classe interrompeu a brincadeira de casamento, mas as mesmas flores que serviram de ramalhete tiveram outra utilidade - fato enaltecido por intermédio de outra criança: A prô ganhou flor de velório e ainda que achou no lixo!

A experiência real da criança com um "velório" permitiu que ela imaginasse que as flores da escola - uma espécie de margarida de jardim - fossem flores utilizadas em velórios. Essas mesmas flores protagonizaram ainda, um "buquê" para brincar de casamento e por fim, um "presente" dado à professora.

Os brinquedos construídos em conjunto com as crianças também se destacaram. Fato que foi relatado pela professora: - Tem uma criança que tem essa estrela cadente pendurada na bolsa até hoje. Eu vi uma criança no Facebook (da outra professora) com essa coroa em casa. Tava tendo uma festinha de aniversário e aí a criança tirou uma foto com essa coroa e pôs no Facebook. Porque o pai dele está no Japão, então acho que ele tirou e colocou no Facebook (DIÁRIO DE CAMPO, 2014).

As crianças - por meio das experiências vivenciadas no cotidiano, com os pares, ou com crianças e pessoas mais experientes - não se limitaram a (re) produzir o que viam ou vivenciavam, mas atribuíram novos significados por meio do lúdico e da imaginação.

\section{DISCUSSÃO}

As brincadeiras, histórias e atividades propostas pela pesquisa permitiram estimular a imaginação das crianças, que assumiram e transmutaram papéis $\mathrm{e}$ personagens. Elas dividiram o espaço com vampiros, piratas, princesas, super-herói, bicho que pega. As crianças brincaram, imaginaram, relacionaram-se; conheceramse melhor; internalizaram e (re) significaram regras; superaram medos (algumas histórias e personagens levados por nós geraram momentos de medo e incertezas, mas foram superados heroicamente pelas crianças).

Para Quintero (2002, p. 147)

[...] tal como afirmou Florestan Fernandes (1979), a criança poderá ser quem bem quiser mamãe, filhinha, vovó, um animal qualquer ou até mesmo uma personagem extraída da literatura infantil, e o será conforme as regras sociais que internalizou sobre quem e como são estes entes gerais, o que fazem e como agem quem desejam ser. Ademais, pela brincadeira a criança se tornará capaz de construir significados para as ações que realiza, utilizando-se de instrumentos e da própria fala para a organização do seu brincar. Significados, 
estes, construídos socialmente e apropriados pelas interações sociais que estabelece.

Durante todo o percurso da pesquisa além de ampliar e estimular a imaginação infantil de forma lúdica - uma das prioridades era ouvir as crianças. Havia grande familiarização delas conosco e tornou-se comum e "esperado" o momento de escuta partilhado com elas durante o recreio.

Muller (2010, p.353) afirma que “[...] se as crianças interagem no mundo adulto porque negociam, compartilham e criam culturas, necessitamos pensar em metodologias que realmente tenham como foco suas vozes, olhares, experiências e pontos de vista". Devido a esse fato, a pesquisa atendeu a várias falas, ideias e pedidos das crianças, que contribuíram ricamente em todo o processo. Nosso objetivo era realizar pesquisas com as crianças - nossas parceiras - e não apenas sobre elas.

No início da pesquisa, em 2011, as atividades lúdicas e imaginativas, não eram valorizadas e nem compreendidas como linguagens imprescindíveis para o amplo desenvolvimento infantil, no que tange os aspectos sociais, culturais, motores, cognitivos, emocionais das crianças.
As brincadeiras contribuíram para estreitar as relações infantis com os pares, com a pesquisadora e com as professoras; assim como ajudaram a ampliar a compreensão sobre a importância das vivências lúdico-imaginativas no contexto, além de promover e ampliar as culturas infantis entre os pares.

Gradativamente, as crianças demonstraram maior criatividade, envolvimento e imaginação, seja nas falas, nas brincadeiras ou formas de expressaremse. Esclareceu-se - por meio da observação atenta, do diálogo constante, da relação com os pares e com os adultos, dos desenhos, das fotos e entrevistas - o quanto os seus mundos são ricos e cheios de significativo e que, por meio de suas culturas infantis, elas expressaram suas formas de pensar, de agir e de se relacionar; sua alegria, (mas também seus anseios, preocupações e desejos); suas falas sinceras, cheias de emoção, de sentimentos e de ensinamentos.

A pesquisa foi importante para os alunos e para as professoras, mas, foi essencial para nós, pesquisadores, já que possibilitou experiências magníficas, permitiu compreender melhor as crianças e suas infâncias; o que desejam o que sentem o que pensam sobre nós, adultos na atualidade.

\section{CONCLUSÕES}




\section{REFERÊNCIAS}

BOCHORNY J. Cultura lúdica e televisão: mediações no contexto escolar. Dissertação apresentada ao Programa de Pós-Graduação em Educação da Faculdade de Ciências e Tecnologia - FCT/ UNESP, 2012.

CORSARO, W. Sociologia da Infância. Porto Alegre: Artmed, 2011.

DELGADO, A C. C. A emergência da Sociologia da Infância em Portugal Revista Educação. Cultura e Sociologia da Infância. Editora Segmento.

DELGADO, A. C. C.; MULLER, F. Sociologia da Infância: pesquisa com crianças. Educ. Soc., Campinas, v. 26, n. 91, p. 351-360, Maio/Ago. 2005.

FERREIRA, M. R. R. “...Porque quando sai de casa fica invisível e não sei onde ele está!". Imergindo nos meandros das culturas da infância... para desocultação dos amigos imaginários das crianças... Interações,. n. 10, p.. 14-38, 2008.

HONORATO, A. R. S. A imaginação e a infância - Texto digital. Disponível em: <http://www.gedest.unesc.net/seilacs/infanc ia aureliahonotato.pdf $>$. Acesso em: 08 jan. 2014.

LIMA, M. R. C.; LIMA, J. M. A ludicidade como eixo das culturas da infância. Interacções, $n$. 27, p.. 207-231, 2013.

MONTEIRO, A. T. M; CARVALHO, L. D. “As coias que não tem nome são mais pronunciadas por crianças": culturas infantis e produção simbólica. Atos de Pesquisa em Educação - PPGE/ME FURB, v.6, n. 3, p. 632657, set./dez. 2011.

MULLER, F.. Infância em perspectiva: políticas, pesquisas e instituições. São Paulo: Cortez, 2010. 255 p.
PAULA, E. Novos murmúrios sobre as metodologias de pesquisa com crianças pequenas: desafios e rupturas. Contrapontos, Itajaí, v.. 8, n. 1, p. 131-146. Jan/abr., 2008.

QUINTERO, J. Sobre a emergência de uma sociologia da Infância: contribuições para o debate. Perspectiva, Florianópolis, v.20, n. Especial, p. 137-162, jul./dez. 2002.

RODARI, G. Gramática da fantasia. São Paulo: Summus, 1982. - (Novas buscas em comunicação; v.11).

SARMENTO, M. J. Imaginário e culturas da infância. Cadernos de Educação, Pelotas, v. 12, n. 21, p. 51-69, 2003.

- As culturas da infância nas encruzilhadas da $2^{a}$ modernidade. In SARMENTO, M. J.; CERISARA, A. B. (Org.). Crianças e miúdos: perspectivas sociopedagogicas da infância e educação. Lisboa: ASA, 2004.

Gerações e alteridade: interrogações a partir da Sociologia da Infância. Educ. Soc., Campinas, v. 26, n. 91, p. 361-378, Maio/Ago. 2005.

SILVA, E. L. Metodologia da pesquisa e elaboração de dissertação. Edna Lúcia da, Estera Muszkat Menezes. 4. ed. rev. atual. Florianópolis: UFSC, 2005.

STORT, E. V. R. Cultura, imaginação e conhecimento A Educação e a formalização da experiência. 1989. 168f. Dissertação (Mestrado) - Universidade Estadual de Campinas - Faculdade de Educação, Campinas, SP.

Recebido para publicação em 12/08/2014

Revisado em 02/09/2014

Aceito em 19/09/2014 